\title{
Uwagi o odpowiedzialności dyscyplinarnej sędziów za rażącą i oczywistą obrazę prawa w polskim systemie prawnym
}

\author{
Paweł Mazur \\ (Uniwersytet im. Adama Mickiewicza w Poznaniu, pawelmn@amu.edu.pl)
}

\section{Uwagi ogólne}

Odpowiedzialność dyscyplinarna jest definiowana w nauce prawa jako „pewnego rodzaju prawo karania osób indywidualnych, aczkolwiek według ich przynależności do dającej się wyodrębnić grupy społecznej-zawodowej (Czarnecki 2013, 68). Powodem wymierzenia kar dyscyplinarnych jest stwierdzenia naruszenia przez przedstawiciela danej profesji standardów etycznych uznanych $\mathrm{w}$ danej grupie zawodowej za wiążące. 0 rzeczonej odpowiedzialności rozstrzygają organy samorządu zawodowego. Jest to uzasadnione tym, że przedstawiciele danego zawodu mają dobre rozeznanie w specyfice swojego środowiska (Kozielewicz 2012,16). Jakie cele przyświecają tej instytucji prawnej?

Służy ona przede wszystkim piętnowaniu i sankcjonowaniu zachowań uznanych przez organy dyscyplinarne za przewinienia dyscyplinarne, a także wydalaniu z profesji sprawców najcięższych przewinień (Czarnecki 2013, 161). Paweł Skuczyński uwydatnił jej funkcje nierepresyjne, mianowicie ochronną oraz integracyjną. Ta pierwsza polega na zapewnieniu osobom podlegającym odpowiedzialności dyscyplinarnej gwarancji niezależności w realizowaniu ich obowiązków zawodowych. Druga zaś na istnieniu mechanizmów samoregulacji danej grupy poprzez wyznaczanie jej od wewnątrz standardów postępowania jej przedstawicieli (Skuczyński 2017, 37).

Odpowiedzialności dyscyplinarnej oprócz przedstawicieli wielu profesji, podlegają również sędziowie. U źródeł ich odpowiedzialności leży niespełnienie pewnych standardów etycznych.

Normodawca wyznaczając je, zdecydował, że urząd sędziego może piastować jedynie ten, kto legitymuje się tzw. nieskazitelnym charakterem (art. $61 \S 1$ pkt 2 Prawo ustroju sądów powszechnych z dnia 27 lipca 2001 roku zwane dalej USP). Prawodawca nie zawarł $w$ przepisach prawa definicji legalnej, która wskazywałaby jak należy interpretować ten zwrot nieostry. Trud ustalania, jaka jest konotacja tego wyrażenia, przypadł nauce prawa.

W jurysprudencji nieskazitelny charakter przedstawia się jako zbiór rozmaitych zalet, jak np. uczciwość, pracowitość, sumienność, cierpliwość, 
otwartość intelektualna (Ereciński, Gudowski \& Iwulski 2009, 212). Jest to jednak pewien zbiór postulatów (Rocławska 2015, 106). W praktyce rzeczony warunek jest interpretowany dość minimalistycznie. Badanie osoby pretendującej do objęcia stanowiska sędziego sprowadza się do ustalenia, czy dana osoba nie przekracza norm prawnych (Rocławska 2015, 102; Laskowski $2005,57)$. W toku postępowania dyscyplinarnego dokonywana jest natomiast wtórna ocena, czy dana osoba z uwagi na zarzucane jej zachowanie nadal legitymuje się tzw. nieskazitelnym charakterem (Borkowski 2012, 209). Jedynie wymierzenie najsurowszej sankcji dyscyplinarnej tj. wydalenia $\mathrm{z}$ zawodu oznacza uznanie, że dana osoba nie posiada rzeczonego charakteru (Rocławska 2015, 104).

Podstawą pociągnięcia sędziego do odpowiedzialności dyscyplinarnej jest uznanie przez organy dyscyplinarne osoby obwinionej za winną przewinienia dyscyplinarnego. Stosownie do przepisu art. $107 \S 1$ USP. za przewinienia służbowe, $\mathrm{w}$ tym za oczywistą i rażącą obrazę przepisów prawa i uchybienia godności urzędu (przewinienia dyscyplinarne), sędzia odpowiada dyscyplinarnie.

$\mathrm{W}$ toku stosownych zabiegów wykładniczych $\mathrm{z}$ tych przepisów możemy odtworzyć kilka norm sankcjonowanych adresowanych do sędziów. I tak:

a) normę zakazującą sędziemu zachowań uchybiających godności urzędu

b) normę zakazująca sędziemu rażącej i oczywistej obrazy przepisów prawa

c) normę zakazującą innych przewinień dyscyplinarnych

Łatwo dostrzec, że znamiona wyżej przedstawionych czynów zabronionych nie są określone w sposób precyzyjny i ścisły, jak to z reguły bywa $\mathrm{w}$ prawie karnym materialnym. $\mathrm{W}$ prawie dyscyplinarnym nie istnieje przeto wyraźny katalog przewinień dyscyplinarnych (Giezek 2016, 90). Brak precyzyjnego opisu przewinień dyscyplinarnych poprzez określenie miejsca, czasu, sposobu działania nie jest dziełem przypadku. Zachowania te mają określane w drodze wykładni przez organy dyscyplinarne (Skuczyński 2017, 41).

Jednakowoż sędzia jako podmiot moralny, który powinien wyróżniać się samodzielnością myślenia nie powinien czerpać wyłącznie z tych źródeł wiedzy o granicach tego, co dozwolone, a co nie. Ani popularne ostatnimi laty kodeksy etyki zawodowej, ani orzecznictwo Sądu Najwyższego, któremu poświęcimy poniżej nieco uwagi, nie powinny stanowić głównych, czy jedynych źródeł poznania powinności moralnych sędziego. Powtarzając za Leszkiem Kołakowskim krytykę kodeksów moralnych, podkreślmy, że tego rodzaju kodeksy skłaniają do wycofywania się z samodzielnych osądów moralnych. Są one wszakże przejawem dążenia do bezpieczeństwa i wyrazem 
pragnienia życia w świecie, gdzie wszelkie decyzje są gotowe (Kołakowski $2000,153)$.

Wydaje się, że sędzia mając do czynienia $\mathrm{z}$ tak nieostrymi sformułowaniami podstaw odpowiedzialności dyscyplinarnej powinien przede wszystkim samodzielnie rozpoznawać co jest dozwolone, a co nie, rozwijając w ten sposób konieczną cnotę roztropności.

To czynienie użytku z kompetencji osądu etycznego winno stanowić podstawę sędziowskiej praktyki moralnej. Za Kohlbergiem określa się ją jako zdolność do wydawania sądów i decyzji, które opierają się na wewnętrznych zasadach, uwieńczonych działaniem w zgodzie z tymi decyzjami (Mazur \& Nowak 2016, 117). Taka zdolność do osądu etycznego jest jednym z warunków objęcia i piastowania urzędu sędziowskiego. Samodzielność myślenia pożądana w sferze oceny dowodów, czy procesie wykładni prawa jest równie istotna w wypadku rozpoznawania, co złe, a co dobre w sferze zawodowej, jak i pozazawodowej.

Wagę tej zdolności u przedstawicieli władzy publicznej podkreślał Immanuel Kant. Filozof z Królewca pisał, że jeśli władze polityczne czują się niezdolne do osądzania, co dobre i co złe, to z tego uwolnieni są również obywatele (Mazur \& Nowak 2016, 17)1. Zdolność do osądu moralnego w wypadku codziennej praktyki zawodowej i niezawodowej jawi się zatem jako zupełnie elementarny przymiot sędziego.

\section{Rażąca i oczywista obraza przepisów prawa jako podstawa odpowiedzialności dyscyplinarnej sędziów.}

Po garści uwag ogólnych pora przejść do problematyki zaanonsowanej w tytule artykułu.

W polu naszych zainteresowań znajdują się odpowiedzialność dyscyplinarna sędziego za rażącą i oczywistą obrazę prawa. Intencją ustawodawcy w tym wypadku było sankcjonowanie aktów stosowania prawa, a nie łamania prawa przez sędziego (Czarnecki 2013, 218).

Co istotne, od sędziego wymaga się nie tylko prawidłowej postawy moralnej, ale także wyróżniających kompetencji zawodowych. Znakomicie wyraża to paremia iura novit curia, która współcześnie winna być interpretowana, jako znajomość również reguł wykładni prawa (Zieliński 2013, 287). Jak się okaże staranność w stosowaniu prawa jest także istotna dla ustalenia, czy sędzia spełnia przedstawione wyżej minimalne standardy moralne.

\footnotetext{
1 Wszelako, na tę okoliczność Kant wyposażył obywateli - już jako autonomicznych prawodawców i podmioty sądzenia - w narzędzia kwalifikacji wszelkich przepisów praktycznych (Nowak 2018, w druku).
} 
Pociąganie do odpowiedzialności dyscyplinarnej za rażące zaprzeczenia tej regule $\mathrm{z}$ uwagi na rażącą i oczywistą obrazę prawa może jednak budzić niepokój.

O ile pociąganie sędziego do odpowiedzialności dyscyplinarnej za przekraczanie norm moralności ogólnej, stanowiących zarazem przestępstwo - np. jazdę samochodem w stanie nietrzeźwości, znieważanie) nie budzi kontrowersji, o tyle takowe mogą pojawić się w związku interesującą nas kategorii przewinień dyscyplinarnych. Mamy bowiem wtedy do czynienia z oceną w postępowaniu dyscyplinarnym aktów stosowania prawa sądowego. Te zaś powinno być podejmowane w warunkach swobody, a nie obawy o pociągnięcie do odpowiedzialności osobistej za wydanie orzeczenia określonej treści. Te obawy oddaje pogląd Sądu Najwyższego zgodnie z którym, sędzia orzekający nie może tkwić w przeświadczeniu, że każde naruszenie prawa spowoduje jego odpowiedzialność dyscyplinarną, albowiem stanowiłoby to ograniczenie zasady niezawisłości sędziowskiej (wyrok SN z 22 lutego 2007 r., SNO 6/07, OSNSD 2007 r., poz. 6). Słowem, postępowanie dyscyplinarne nie może służyć jako instrument do wymuszania określonej linii orzeczniczej i łamania niezawisłości sędziowskiej.

Kształtując model odpowiedzialności dyscyplinarnej za tego rodzaju przewinienia, trzeba mieć zatem na względzie dwie istotne okoliczności istotnie wpływające na zakres tej odpowiedzialności: po pierwsze, tolerancję normodawcy dla rozbieżności w ocenach i rozmaitych rozstrzygnięciach, które pozostają pod ochroną, jeśli spełniają pewne kryteria (Wróblewski 1976, 357 358). Czynienie użytku z norm kompetencyjnych przez sądy odbywa się odbywa się w granicach luzów decyzyjnych. Te obejmują między innymi ocenę wiarygodności dowodów, decyzje kwalifikacyjne, walidacyjne, interpretacyjne Swoje piętno na treści decyzji odciskają także właściwości osobiste sędziów. Istotne rolę może odgrywać również korygowanie prawa poprzez odwoływanie się przez sędziów do znanej od Arystotelesa kategorii słuszności (Pietrzykowski 2012, 216). Rozmaitej treści wyroki zapadające w rezultacie tak dalece zindywidualizowanych ocen pozostają zatem pod ochronę, jeśli tylko rozumowania sędziowskie, które do nich doprowadziły spełniały pewne kryteria. Sędzia nie musi zatem obawiać się zakwalifikowania wydanego przezeń orzeczenia, jako rażąco i oczywiście naruszającego prawo, jeśli spełni tylko pewne kryteria.

Po drugie, zasadniczą formą reakcji na błędy w stosowaniu prawa jest kontrola odwoławcza, które może doprowadzić do skorygowania, bądź uchylenie orzeczenia, lecz bez pociągania do osobistej odpowiedzialności sędziego (Wróblewski 1976, 362). Odpowiedzialność dyscyplinarna, tak jak postępowanie kontrolne jest również formą reakcji na naruszenia prawa przez sędziego $w$ toku procesu stosowania prawa. Tyle, że w centrum uwagi znajduje się nie tyle obarczony wadą prawną rozstrzygnięcie, co przede wszystkim autor decyzji, którego stawia w bardzo złym świetle. 
W kształtowaniu standardów odpowiedzialności dyscyplinarnej sędziów bardzo ważną rolę spełnia Sąd Najwyższy oraz w pewnym stopniu sądy apelacyjne rozpoznające sprawy dyscyplinarne, jako sądy I instancji. Najwyższa Instancja Sądowa rozpoznając środki odwoławcze od orzeczeń sądów dyscyplinarnych przedstawiła swoją wykładnię przewinienia rażącej i oczywistej obrazy przepisów prawa. Sąd Najwyższy wydał wiele orzeczeń w postępowaniach dyscyplinarnych i nie miejsce w niniejszym opracowaniu na ich referowanie. Jednakże warto podjąć próbę wyłuszczenia wiodących i zasadniczych tez Sądu Najwyższego i następnie opatrzyć je krytycznymi komentarzami, a także wskazać zachowania napiętnowane przez rzeczony sąd, jako rażąca i oczywista obraza przepisów prawa.

Według Sądu Najwyższego tego rodzaju uchybienie ma miejsce wówczas, gdy obraza prawa ma charakter oczywisty tj. gdy jest łatwa do stwierdzenia, a zastosowanie właściwego przepisu prawa (a więc jej uniknięcie) nie powinno budzić wątpliwości u przeciętnej osoby o kwalifikacjach prawniczych. Najwyższa Instancja Sądowa uznała nadto, że obraza prawa ma charakter rażący, jeżeli powoduje szkodę lub naraża na szwank prawa i istotne interesy stron biorących udział w postępowaniu. Taka wykładnia rzeczonego zwrotu niedookreślonego pojawia się $\mathrm{w}$ wielu orzeczeniach (wyroki SN z dnia 28 czerwca 2002 r., SNO 18/02, OSNSD 2002, nr 1-2, SNO 18/02, OSNSD 2002, nr 1-2, poz. 9, wyrok Sądu Najwyższego z dnia 8 czerwca 2017 r., SNO 22/17, nr 16111991 Legalis).

Sąd Najwyższy podkreślał konieczność ochrony władz dyskrecjonalnej sędziego, wywodząc, że odpowiedzialność dyscyplinarna dotyczy przede wszystkim stosowania tzw." przepisów porządkowych nie mających związku z orzekaniem". W orzecznictwie SN zaakcentowano, że zasadnicze znaczenie ma to, jaki charakter ma norma, której obrazy dopuścił się sąd tj. czy jej stosowanie opierało się na elementach o cennych, czy stanowiło wykładnie i stosowania przepisów porządkowych bądź mających odległy związek z orzekaniem (Skuczyński 2017, 90).

Za rzeczone przewinienia dyscyplinarne $w$ rozpoznawanych sprawach dyscyplinarnych uznano między innymi:

- antydatowanie zarządzenia o przekazaniu spraw innemu sędziemu (wyrok SN z 17 października 2006 r., SNO 59/06, OSNSD poz. 66)

- dokonywanie zmian $\mathrm{w}$ wyroku $\mathrm{w}$ trybie nieprzewidzianym $\mathrm{w}$ procedurze (wyrok SN z dnia 28 listopada 2002 r., SNO 43/02, OSNSD 2002 r., poz. 45)

- wydanie postanowienia o tymczasowym aresztowaniu pomimo upływu przewidzianego ustawowo terminu (wyrok SN z dnia 28 maja 2008 r., SNO 34/08, OSNSD 2008, poz. 54).

- błędy w niezawisłym orzekaniu, ale tylko za oczywiste, czyli kwalifikowane bezprawie sądowe (wyrok SN z 7 maja 2008 r., SNO45/08, OSNS 
Niemała grupa orzeczeń Sądu Najwyższego piętnuje rozmaite opóźnienia w wykonywaniu doniosłych procesowo czynności jak np. sporządzania uzasadnień wyroków w ustawowym terminie. I tak tytułem przykładu uznano za przewinienia dyscyplinarne takie zachowania jak nieterminowe sporządzanie uzasadnień (OSNSD 2002, nr 1-2, poz. 14), czy doprowadzenie do przewlekłości postępowania (wyrok SN z dnia 27 stycznia 2003 r., SNO 56/02, OSNSD 2003, nr 1, poz. 18).

Poglądy Sądu Najwyższego usposabiają do polemiki. Nietrudno w tym miejscu o spostrzeżenie, że naruszenia prawa osądzone jako przewinienie dyscyplinarne, dotyczyło rażących błędów, które były też przykładem ewidentnych braków wiedzy prawniczej i niedbalstwa warsztatowego. Jednakże nie usuwa to powstałych wątpliwości. Prawdziwą zagadką jest bowiem, co oznacza rozpoznanie tego uchybienia z punktu widzenia osoby o „przeciętnej wiedzy prawniczej". Przybranie takiej perspektywy poznawczej przez sędziego Sądu Najwyższego, z założenia wysoko wykwalifikowanego prawnika, musi nastręczać nie lada trudności, by nie rzec - jest niemożliwe, a ponadto nieuchronnie wikła organ dyscyplinarny w spekulacje. Posługiwanie się wzorcem przeciętnego prawnika przez Sąd Najwyższy nie spełnia kryteriów racjonalności zewnętrznej. Decyzja racjonalna zewnętrznie to taka, jaką podjąłby ten, kto analizuje ją $\mathrm{z}$ zewnętrznego punktu widzenia ją (Wróblewski 1975, 267). Posługiwanie się figurą przeciętnego prawnika w orzecznictwie dyscyplinarnym jawi się zatem dla odbiorców orzeczeń, jako niejasne i trudno dociec, co oznacza w konkretnym przypadku optyka tzw. przeciętnego prawnika.

Sąd Najwyższy w kategoriach rażącej obrazy przepisów prawa interpretuje również opieszałość sędziów w podejmowaniu czynności procesowych. Wydaje się, że jest to efekt przyjęcia, jako miarodajnych reguł racjonalności instrumentalnej. Wyraża się ona $\mathrm{w}$ realiach wymiaru sprawiedliwości w oczekiwaniu od sędziów maksymalnej efektywności. Takie akcentowanie wydajności, efektywności zbliża sędziego do Arendtowskiego homo faber, który musi nadawać się do tego, aby być narzędziem do osiągnięcia jakiegoś celu, tj. podmiotu, który myśli jedynie w kategoriach środków i celów (Arendt 2010, 183). Oczywiście sprawne rozstrzyganie sporów między obywatelami jest uzasadnionym oczekiwaniem wobec sędziów. Jednakże oceny tego rodzaju winny być ferowane nader ostrożnie, z uwzględnieniem niekiedy poważnego obciążenia sprawami i przeciążenia sędziów. Płynie stąd wniosek dość banalny: opieszałość w rozpoznawaniu spraw nie musi wynikać $\mathrm{z}$ niedbalstwa czy lekceważącego stosunku do własnych powinności, lecz z problemów natury systemowej, których, co oczywiste, nie rozwiążą sankcje dyscyplinarne wymierzane sędziom.

Dużym uproszczeniem jest stanowisko Sądu Najwyższego zgodnie z którym ocenie $\mathrm{w}$ postępowaniu dyscyplinarnym podlegają akty stosowania prawa nie oparte na ocenach i mające „odległy związek z orzekaniem”. Z 
drugiej strony zrozumiała jest troska Sądu Najwyższego o ochronę swobody ocen $\mathrm{w}$ procesie sądowego stosowania prawa i ochrony niezawisłości sędziowskiej i ograniczanie kontroli dyscyplinarnej do stosowania norm kompetencyjnych nie dotyczących bezpośrednio wyrokowania. Szkopuł w tym, że i stosowanie tzw. przepisów porządkowych niemających związku z orzekaniem jest oparte na ferowaniu ocen i podejmowaniu decyzji ważkich dla obywateli poddanych władzy sędziowskiej. Obrazuje to spojrzenie na problematykę podejmowanie tego czynności z pionierskiej perspektywy formalizacji i konwencjonalizacji czynności procesowej autorstwa Barbary Janusz-Pohl.

Stosowanie „przepisów porządkowych” to innymi słowy podejmowanie czynności procesowych. Stosownie do najnowszej definicji autorstwa Barbary Janusz-Pohl czynność procesowa to „sformalizowana czynność konwencjonalna doniosła prawnie, która polega na świadomej i dowolnej realizacji substratu materialnego w celu dokonania tej czynności (zgodny z właściwymi dla niej regułami konstytutywnymi" (Janusz-Pohl 2017, 93). Ich prawidłowe i ważne wykonanie wymaga zaś rozpoznania w procesie wykładni przepisów i prawidłowej aplikacji reguł formalizacji i konwencjonalizacji. Reguły konwencjonalizacji podważają byt danej czynności procesowej, natomiast naruszenie reguł formalizacji powoduje, że dana czynność przyjmuje charakter wadliwy (Janusz-Pohl 2017, 51).

Ten, kto chce w sposób prawidłowy i ważny dokonać określonej czynności procesowej musi najpierw w procesie wykładni prawa dokonać stosownych ocen, aby odpowiednio do określonego stanu faktycznego zidentyfikować i aplikować te reguły. Podjęcie takich czynności może również często mieć istotne znaczenie dla wolności i praw obywatelskich. Podejmowanie czynności porządkowych jak np. odmowy przyjęcia rozmaitych wniosków, kontroli formalnej pism procesowych rządzą reguły formalizacji i konwencjonalizacji, które muszą być odpowiednio rozpoznane przez sąd i zastosowane.

Stosowny proces oceny musi zostać uruchomiony choćby przy podejmowaniu czynności procesowych związanych $\mathrm{z}$ kontrolą formalną apelacji wniesionej przez osobę nieuprawnioną (Janusz-Pohl 2017, 470). Trudno zatem wyeliminować oceny sędziowskie z procesu stosowania tzw. „przepisów porządkowych”. Z tych powodów rozumowanie Sądu Najwyższego jawi się jako co najmniej dyskusyjne.

\section{Uzasadnienie sankcjonowania rażącej i oczywistej obrazy przepisów prawa}

Nie budzi kontrowersji konieczność pociągania sędziego do odpowiedzialności dyscyplinarnej za tego rodzaju zachowania jak np. przemoc stosowana wobec domowników, czy obelżywe zwracanie się do stron. Są to 
zachowania sprzeczne z normami moralności ogólnej uznawanej przez znakomita część społeczeństwa i piętnowanie sędziego, który się ich dopuszcza jawi się jako oczywiste. Tej oczywistości nie odnajdujemy w wypadku karania rażącej obrazy przepisów prawa. Gdzie upatrywać uzasadnienia silnej dezaprobaty moralnej dla aktów rażącej i oczywistej obrazy przepisów prawa? Dlaczego uchybienia w stosowaniu prawa mogą stawiać sędziego w złym świetle, jako podmiot moralny i doprowadzić do podważenia $w$ toku postępowania dyscyplinarnego domniemania, że posiada nieskazitelny charakter.

Wydaje się, że naganność rażącej i oczywistej obrazy przepisów prawa wynika z naruszenia lojalności sędziów wobec osób poddanych ich władzy. Relację obywatel-sędzia można wyjaśnić za pomocą pojęcia stosunku podległości kompetencji, którego autorem jest Zygmunt Ziembiński. Autor przedstawiając rzeczony stosunek zwrócił uwagę na dwa typy norm, mianowicie: a) normę udzielająca kompetencji do stanowienia norm indywidualnych i konkretnych (na podstawie, których następuje konkretyzacja praw i obowiązków określonych podmiotów a także b) normę udzielającą kompetencji do dokonania czynności prawnej przez którą aktualizuje się obowiązek prawny jakiegoś podmiotu (Janusz-Pohl 2017, 139-140; Ziembiński 1980, 332). Obywatele znajdując się relacji podrzędności wobec sędziów wykonujących powierzone im kompetencje do wydawania decyzji, mają obowiązek reagować na podjęcie czynności konwencjonalnej w postaci wydania wyroku poprzez danie mu posłuchu, zniesienie uciążliwości związanych z jego wykonaniem.

Powierzenie pewnej osobie ogromnej władzy, w dodatku w bardzo ograniczonym stopniu kontrolowanej i oparte na swobodzie ocen wiąże się z ryzykiem. Zapożyczając semantykę od Hannah Arendt, można je określić mianem ryzyka działania wpisanego w ludzką działalność. Odpowiedzią na ryzyko związane ze sprawowaniem władzy sędziowskiej jest instytucja przysięgi. Ma ona u swego źródła niespolegliwość człowieka. Polega ona na tym, że człowiek nie może zaręczyć kim będzie jutro, jakie podejmie działania. Składanie obietnic pozwala nam natomiast panować $\mathrm{w}$ jakimś stopniu nad przyszłością (Arendt 2010, 277). W wypadku nas interesującym przysięga stanowi dla sędziego, któremu powierzono władzę- źródło ograniczeń i podstawę do egzekwowania odpowiedzialności w wypadku jej naruszenia. To właśnie przysięga stanowi źródło zobowiązania do lojalnej postawy wobec obywateli.

W jednym ze swoich orzeczeń Sąd Najwyższy wprost wskazał że akt ślubowania sędziowskiego nie ma charakteru wyłącznie emblematycznego, symbolicznego, lecz także materialny, gdyż rota ślubowania wytyczna granice, których przekroczenie oznacza popełnienie przewinienia służbowego i rodzi odpowiedzialność dyscyplinarną (wyrok SN z dnia 1 grudnia 2017 r.). Treść tej przysięgi brzmi następująco: „Ślubuję uroczyście jako sędzia sądu 
powszechnego służyć wiernie Rzeczypospolitej Polskiej, stać na straży prawa, obowiązki sędziego wypełniać sumiennie, sprawiedliwość wymierzać zgodnie z przepisami prawa, bezstronnie według mego sumienia, dochować tajemnicy prawnie chronionej, a w postępowaniu kierować się zasadami godności i uczciwości" (art. 66 USP).

Wypowiedzenie słów przysięgi ma nie tylko moc performatywną polegającą na powołaniu do pełnienia urzędu sędziego. Jest jednocześnie dobrowolnym podjęciem przed społeczeństwem poddanym władzy sędziowskiej określonego zobowiązania i stanowiącym podstawę do egzekwowania pewnych oczekiwań. $\mathrm{W}$ tym wypadku $\mathrm{z}$ racji przedstawionego wyżej stosunku nadrzędności, nie mamy do czynienia $\mathrm{z}$ umówieniem się sędziego oraz społeczeństwa, co do pewnych zachowań. Jednakże nie osłabia to wagi podjętego zobowiązania.

Stosowanie prawa służy wszakże spełnieniu oczekiwań wobec obywateli wynikających z roli zawodowej spełnianej przez sędziów, którzy znajdują się w relacji podporządkowania organów władzy sędziowskiej. To oczekiwanie wyraża się właśnie w unikaniu rażących błędów w stosowaniu prawa, u których podstaw legła niewiedza, zła wola, czy ignorancja (Andre 2010, 212). Dodajmy, że sędziowskie stosowania prawa jest poza wieloma innymi aspektami także wykonywaniem pracy. Stosowanie prawa z rażącą i oczywistą obrazą można porównać do jednej z postaci Tischnerowskiego moralnego wyzysku pracy, zachodzącego tam gdzie praca odrywa się celów etycznych, którym ma służyć (Tischner 1992, 86).

Dodatkowym źródłem zobowiązania moralnego jest obowiązek określony przez Johna Rawlsa mianem fair play. Ten obowiązek aktualizuje się wraz z przyjęciem przez dany podmiot pewnych korzyści. Przywołana wyżej Judith Andre, powołując się na przywołany pogląd Johna Rawlsa, zwróciła uwagę, że „jeśli ktoś dobrowolnie przyjmuje korzyści powstałe dzięki wysiłkowi grupowemu, to jest on zobowiązany do dokonania wkładu w ów wysiłek. Pełniący określoną rolę otrzymuje korzyści i nabywa określone obowiązki (Andre 2010, 219-220). Akt przyrzeczenia sędziowskiego jest dobrowolnym przyjęciem na siebie obowiązków orzeczniczych, ale również uzyskaniem szeregu przywilejów od wspólnoty politycznej. Dość wspomnieć: immunitet chroniący przed pociągnięciem do odpowiedzialności karnej, nieusuwalność, czy stan spoczynku. Sędzia beneficjent tego rodzaju korzyści ma obowiązek stosowania prawa w sposób rzetelny, przy dołożeniu należytej staranności i przybrania postawy intelektualnej polegającej na dociekliwości i podwyższaniu swoich kompetencji zawodowych.

Rażąca i oczywista obraza przepisów prawa jest sprzeniewierzeniem się etosowi sędziowskiemu. $\mathrm{W}$ etosie sędziowskim istotną rolę powinna odgrywać również pewna postawa intelektualna polegająca na zdobywaniu wiedzy, otwartości na krytykę, czy gotowości nieustannego uczenia się. Wagę moralną wiedzy/niewiedzy pięknie oddają słowa Barbary Chyrowicz. Sądzę, 
że można je z powodzeniem odnieść do wagi wiedzy w wypadku sądowego stosowania prawa:

Odpowiadamy moralnie za brak wiedzy, którą moglibyśmy zdobyć, o ile ta miałaby wpływ na nasze działanie, w sposób szczególny na redukowane jego niekorzystnych skutków. Wiedza jest moralnie doniosła! To oznacza również odpowiedzialność za wiedzę natury moralnej. Jej zdobywanie nie jest rzeczą banalną Wysiłek poznawczy związany z przezornością i umiejętnością przewidywania skutków jest moralnym obowiązkiem - za skutki pozostajemy odpowiedzialnej tylko tak dalece jak byliśmy $\mathrm{w}$ stanie to przewidzieć (Chyrowicz 2016, 112).

Już elementarna powinność sędziego w procesie orzekania, jaką jest wykładnia prawa, wymaga wiedzy (prerozumienia intelektualnego), kreatywności, inteligencji oraz mądrości życiowej (Rocławska 2015, 88). Ten, kto zaniedbuje ten intelektualny wymiar etosu sędziowskiego, podejmuje ryzyko popełniania poważnych błędów w stosowaniu prawa.

\section{Uwagi końcowe}

Być może warto podjąć próbę przemyślenia na nowo podstaw odpowiedzialności dyscyplinarnej sędziów za przedstawione wyżej przewinienia.

Przemawiają za tym rosnące oczekiwania społeczne wobec sędziów, a także komplikowanie się współczesnego świata. Ani świat, ani prawo nie będą już proste, jak trafnie skonstatował Ryszard Sarkowicz (2005, 67). Współczesny sędzia orzekając $\mathrm{w}$ takim świecie musi już u progu wylegitymować się określonym zasobem wiedzy o wykładni, umiejętności argumentowania i rozwijania również kompetencji w zakresie osądu moralnego.

Podwyższenie standardów, a co za tym idzie rozszerzenie zakresu normowania interesujących nas deliktów dyscyplinarnych wcale nie musi sprzeciwiać się zasadzie niezawisłości sędziowskiej. Ten kto chce być jej beneficjentem musi spełniać pewne wymagania, zwłaszcza jeśli chodzi o poziom stosowania prawa.

To sami sędziowie mogą w drodze praktyki orzeczniczej podwyższać ten standard i uznawać za orzeczenia wydane z rażącą i oczywistą przepisów prawa np. te, które zostały wydane wskutek całkowicie dowolnej oceny dowodów, nierespektowania zasady racjonalności, czy też niestosowania reguł wykładni.

Na koniec kilka słów na temat zmiany ustawodawczej, która być może doprowadzi do zmiany standardów w tym zakresie. Novum stanowi tu ustawa o Sądzie Najwyższym z dnia 8 grudnia 2017 r. Przewiduje ona utworzenie Izby Publicznej i Izby Dyscyplinarnej (art. $3 \S 4$ ustawy) w skład, której wchodzą 
wyłonieni przez Senat ławnicy (art. $59 \S 1$ ustawy). Wyżej wymienione osoby będą wraz $\mathrm{z}$ sędziami zawodowymi rozpoznawały środki zaskarżenia od orzeczeń sądów dyscyplinarnych. Oznacza to $\mathrm{w}$ istocie, że standardy będą wyznaczane przez osoby wywodzące się spoza środowiska sędziowskich. Jest to odejście od zasady, zgodnie, z którą reguły odpowiedzialności wyznaczają autonomicznie przedstawiciele zawodu. Z drugiej strony nadarza się sposobność, aby sędziowie społeczni przedstawiali swoją wizję standardów odpowiedzialności dyscyplinarnej za oczywistą i rażącą obrazę prawa. To oni będą współkształtować standardy odpowiedzialności dyscyplinarnej. Otwarte pozostaje pytanie, w jaki sposób sędziowie społeczni uczynią użytek z tych kompetencji.

\section{Literatura}

Andre J. 2010. "Moralność ról jako złożony przypadek zwyczajnej moralności", w: W. Galewicz (red.), Moralność i profesjonalizm. Spór o pozycję etyk zawodowych. Kraków: Universitas.

Arendt H. 2010. Kondycja ludzka, przeł. A. Łagodzka. Warszawa: Aletheia.

Borkowski G. 2012. "Nieskazitelność charakteru a powołanie do wykonywania zawodów prawniczych", w: G. Borkowski (red.), Etyka zawodów prawniczych $w$ praktyce. Wzajemne relacje i oczekiwania. Lublin: Verba (205-214).

Chyrowicz B. 2016. "Moralne uwarunkowania kondycji ludzkiej". Przegląd Filozoficzny 1:102-121.

Czarnecki P. 2013. Postępowanie dyscyplinarne wobec osób wykonujących prawnicze zawody zaufania publicznego. Warszawa: C. H. Beck.

Ereciński T., Gudowski J., \& Iwulski J. 2009. Prawo o ustroju sq̨dów powszechnych. Ustawa o Krajowej Radzie Sądownictwa. Komentarz. Warszawa: Lexis-Nexis.

Giezek J. 2015. "Interes społeczny jako kryterium legalności działań prokuratorskich", w: B. Namysłowska-Gabrysiak, K. SyrokaMarczewska, \& A. Walczak-Żochowska (red.), Prawo wobec problemów społecznych. Księga jubileuszowa prof. Eleonory Zielińskiej. Warszawa: C. H. Beck (89-99).

Janusz-Pohl B. 2017. Formalizacja i konwencjonalizacja jako instrumenty analizy czynności karnoprocesowych $w$ prawie polskim. Poznań: Wydawnictwo Naukowe UAM.

Kozielewicz W. 2012. Odpowiedzialność dyscyplinarna sędziów, prokuratorów, adwokatów, radców prawnych i notariuszy. Warszawa: Lexis-Nexis.

Laskowski M. 2008. "Ustawowe pojęcie 'nieskazitelność charakteru'". Prokuratura i Prawo 6:50-65.

Nowak E. \& Mazur P. 2016. "How Moral Judgment Competence Fosters Discretionary Powers: A Dillematic Approach", w: M. Zirk-Sadowski, B. 
Wojciechowski, \& R. Hauser (Eds.), Common European Constitutional Culture. Frankfurt am Main - Bern - New York: Peter Lang Editions (117-134).

Nowak E. 2018 (w druku). "Transcendentalne pryncypium prawa: obowiązywanie vs. przymus", w: Ideosfera Marka J. Siemka: współmyślenie, dyskusje, eksploracje. Warszawa: Wydawnictwo UW.

Pietrzykowski T. 2012. Intuicja prawnicza $W$ stronę zewnętrznej integracji teorii prawa. Katowice: Diffin.

Rocławska A. 2015. Czy polski ustawodawca wymaga od sędziów dzielności etycznej? Rozważania na tle ustawowego wymogu nieskazitelności charakteru. Wrocław: Ogrody Nauk i Sztuk.

Tischner J. 1992. Świat ludzkiej nadziei. Kraków: Wydawnictwo Znak.

Wróblewski J. 1976. "Kontrola decyzji sądowej-wybrane zagadnienia teoretyczne". Państwo i Prawo 8/9:18-31.

Wróblewski J. 1972. Sq̨dowe stosowanie prawa. Warszawa: PWN.

Sarkowicz R. 2005. "Polska kultura prawna a proces integracji europejskiej", w: S. Wronkowska (red.), Uwagi o współczesnej interpretacji prawniczej. Warszawa: Wydawnictwo Wolters Kluwer (11-31).

Skuczyński P. 2017. "Bezpośrednie stosowania Konstytucji RP przez sądy a odpowiedzialność dyscyplinarna sędziów". Kwartalnik o Prawach Człowieka 3-4:88-95.

Skuczyński P. 2017. "Nierepresyjne funkcje odpowiedzialności dyscyplinarnej a model postępowania w sprawach dyscyplinarnych". Przegląd Legislacyjny 3:35-53.

Zieliński M. 2011. "Iura novit curia", w: S. Lewandowski, H. Machińska, \& J. Petzel (red.), Prawo, język, logika. Księga jubileuszowa Profesora Andrzeja Malinowskiego, Warszawa: Wolters Kluwer (287-304). 


\title{
Paweł Mazur (Poznań)
}

\section{Notes on Disciplinary Responsibility of Judges for Blatant and Obvious Violations of Law in Polish Legal System}

\begin{abstract}
The paper deals with the disciplinary responsibility of judges for obvious and flagrant legal misconduct. A model of the aforementioned responsibility in the Polish law has been presented. The problems deliberated upon include: the moral justification of punishing judges for mentioned disciplinary delicts and critical evaluation of Supreme Court view about this responsibility. A question is asked about reconsidering the interpretation of obvious and flagrant legal misconduct according to modern times and the complicated social and law reality.
\end{abstract}

Keywords: disciplinary responsibility, judges, misconduct, Supreme Court, Polish legal framework

Ethics in Progress (ISSN 2084-9257). Vol. 8 (2017). No. 2, Art. \#8, pp. 97-109.

Creative Commons BY-SA 3.0

Doi: 10.14746/eip.2017.2.8 